\title{
RELATIONSHIP BETWEEN NUTRITION INTAKE AND THE FITNESS OF MANUFACTURING WORKERS IN INDONESIA
}

\author{
Muhammad Ilyas ${ }^{1,3}$, Dewi Sumaryani Soemarko ${ }^{1,3}$, Nuri Purwito Adi ${ }^{1,3}$, Dewi Yunia Fitria ${ }^{1,3}$, Marsen \\ Isbayu Putra ${ }^{1,3}$, Yessi Kualasari ${ }^{2}$ \\ ${ }^{1}$ Department of Community Medicine, Faculty of Medicine, University of Indonesia, Indonesia \\ ${ }^{2}$ Ministry of Manpower of the Republic of Indonesia, Indonesia \\ ${ }^{3}$ Occupational Environmental Health and Research Center IMERI FKUI, Indonesia \\ Alamat korespondensi: Muhammad Ilyas \\ Email:muhammadilyas@ui.ac.id
}

\begin{abstract}
ABSTRACK
Indonesia ranks fourth in the world out of 15 countries whose manufacturing industries contribute more than $10 \%$ to the Gross Domestic Product (GDP). Nowadays, one of the consequences of the rapid development of the manufacturing industry in Indonesia is related to work productivity. Each person's work productivity is not the same, one of them depends on the availability of nutrients in the body. Lack of nutritional consumption for someone from standard needs will affect health conditions, activities, and work productivity. Nutritional substances in workers also affect fitness in addition to other factors such as age, health status, nutritional status, nutritional status, gender, and psychological conditions. Based on the description above, it is necessary to study the relationship between nutritional status and physical fitness of workers in manufacturing companies in Indonesia. The study was cross sectional on 120 workers from 6 manufacturing companies in Indonesia which was conducted using cluster sampling. Assessment of individual characteristics was conducted by direct interview. Assessment of nutritional intake uses the Food Frequency Questionnaire (FFQ) and the results were categorized as appropriate and inappropriate based on the 2019 nutritional adequacy figure for the Indonesian population. The fitness assessment (physical capacity) used a six-minute walking test by an occupational specialist and was converted to Meters and categorized with a cut off of 4.5 Mets to be sufficient or insufficient. About one third of manufacturing workers were centrally obese. Characteristics The dietary intake according to the recommendation were only about $10 \%$, namely the appropriate carbohydrate intake $11.7 \%$ (Frequency 8.46 times (533.22 gr)), suitable fat $12.5 \%$ (Frequency 2.75 times (57.14 gr)), and suitable protein 10\% (Frequency 6.55 times (101.77 gr)). The physical capacity of manufacturing workers in Indonesia was categorized as sufficient as much as $75.8 \%$ of their workload. Factors that affect physical capacity, namely age $\geq 40$ years have 4.37 times less physical capacity and protein intake affected physical capacity / fitness for workers $(\mathrm{p}=0.02)$. About a third of manufacturing workers were centrally obese. The characteristic of food intake in accordance with the recommended nutritional adequacy of the Indonesian population was only about $10 \%$. The physical capacity of manufacturing workers in Indonesia was categorized as sufficient as much as $75.8 \%$ of their workload. Factors that affected physical capacity were age and protein intake.
\end{abstract}

Keywords: Food Intake, Food Frequency Questionnaire (FFQ), Manufacturing Worker, Fitness, Six-Minute Walking Test.

\section{INTRODUCTION}

Based on data released by (Basic Health Research, 2018), Indonesia was ranked fourth in the world out of 15 countries whose manufacturing industries contribute more than $10 \%$ to Gross Domestic Product (GDP). The development of the industrial sector cannot be separated from the role of the workforce even though many companies use sophisticated machines and technology in their production processes. One of the consequences of the rapid industrial development and intense competition between companies are the productivity of workers. Productivity is a universal concept that creates more goods and services for human needs, using limited resources. Basically, (Yuan et al., 2018) said productivity was influenced by three factors, namely workload, work capacity and additional load due to the work environment. Workload relates to physical, 
mental and social loads that affect labor. Work capacity relates to the ability to complete work at a certain time. Meanwhile, the additional burden due to the work environment includes physical, chemical and labor factors, which include biological, physiological, and psychological factors. Each person's work productivity is not the same, one of them depends on the availability of nutrients in the body. Lack of nutritional consumption for someone from the minimum standard will generally affect physical fitness, work activities, and productivity.

Physical fitness is the main asset for all human life. Labor requires good physical fitness to work, thus it can increase work power and high productivity. According to (Grimani, Aboagye and Kwak, 2019) "physical fitness is the ability of a person to do daily work efficiently without excessive fatigue thus he can enjoy his spare time". Physical fitness is one aspect of total fitness.

Physical fitness is important for everyone to live their daily life. (Shearer, Graham and Skinner, 2016) said the role of other factors that may influence the health and productivity of workers, such as nutrition, is generally overlooked. Based on the above opinion, it is clear that every physical activity (physical activity is subject to a load) requires a level of physical fitness which is supported by nutrition.

Overall physical fitness (total fitness). Physical fitness gives a person the ability to do daily productive work without excessive fatigue and still has reserves of energy to enjoy his free time well or do sudden work.

Good physical fitness is the main basic capital for workers to do physical activity repeatedly in a relatively long time without causing significant fatigue. By having good physical fitness, it is hoped that workers will be able to work productively and efficiently. Factors that support physical fitness in the industry vary widely, influenced by workload, work environment, physical problems, and health conditions. Physical fitness can also be influenced by individual factors such as age, health status, nutritional status, nutritional status, gender, and psychological conditions. Based on the description above, it is necessary to study the relationship between nutritional status and physical fitness of workers in companies in Indonesia.

\section{METHOD}

This research was using cross sectional study design (cross-sectional) on manufacturing workers in 6 companies spread over the areas of Bandung, Surabaya, Medan, Semarang, Makassar, and Samarinda which were determined based on cluster sampling. The number of samples in this study were 120 people. The research instrument used in this study was a respondent characteristic questionnaire to see individual factors written in numerical and categorical form. For food intake using (Fahmida Umi, 2011), the Food Frequency Questionnaire (FFQ) was written in grams, then compared to the 2019 Nutritional Adequacy Rate of the Indonesian population (Ministry of Health Republic of Indonesia, 2019) and categorized as appropriate and inappropriate (more and less). The fitness assessment was conducted by means of a six-minute walking test by (Issues et al., 2002) which was converted into Mets and categorized as being insufficient and sufficient with a cut-off value of 4.5 Mets. This research was assisted by enumerators from each region with a minimum requirement of a S1 nutrition education and the previous perceptions were equated. The Six-minute walking test was performed by an occupational specialist. This research has passed the ethical test from the Faculty of Medicine, University of Indonesia with No: 007/UN.2.F1/ETIK/2019.

Inclusion criteria was being with a manufacturing company for at least three months and willing to participate in research and have signed an informed consent and for exclusion only not willing to take part in research. 
Data collection was collected by researchers on weekdays from 08.00-16.00 WIB for approximately three weeks. Respondents were manufacturing workers who work in manufacturing companies spread across six regions in Indonesia. The process of selecting prospective respondents began with providing information about the aims and objectives of the study, then continued with a short interview for respondent selection, and approval of prospective respondents according to the criteria of the research subject will be asked to participate in the research. Furthermore, an interview was conducted and given an explanation of how to fill out the questionnaire and how to do the 6 minutes walking test. Respondents will fill out a questionnaire accompanied by a researcher and a research assistant, namely a doctor who has been trained and will undergo a fitness test.

Data processing was performed using the SPSS 20.0 program. Data obtained will be entered into a computer and then analyzed by univariate and bivariate. Univariate analysis was conducted to see the frequency distribution of all the variables studied, including: demographic characteristics, individual characteristics, occupation. In the univariate test, normality was assessed using the Kolmogorov Smirnov test. Bivariate analysis aims to see the relationship of each variable. The $p$ value which was considered significant was $<0.05$. The bivariate test used for categorical and categorical variable tests used Chi-Square or Fisher and for categorical and numeric variables tested by the Independent T-Test or Mann-Whitney test.

\section{RESULT}

Data collection in this study took 2 weeks in 6 types of manufacturing companies in Indonesia. These three types of companies are engaged in food, vehicles, and goods. It was obtained the distribution of individual characteristics as follow:

Table 1. Individual Characteristics in the Numeric Variable of Research Subjects

\begin{tabular}{|c|c|c|}
\hline No & Variable & Mean/Median \\
\hline 1 & Age & $35.5(21-56)$ years \\
\hline 2 & Years of service & $11.5(1-39)$ years \\
\hline 3 & Length of Sleep & $6.54(+/-1.61)$ hours \\
\hline 4 & Weight & $64.5(33-127) \mathrm{kg}$ \\
\hline 5 & Height & $164.44(+/-6.48) \mathrm{cm}$ \\
\hline 6 & Abdominal Circumference & $84.96(+/-12.54) \mathrm{cm}$ \\
\hline 7 & $\begin{array}{l}\text { Road Test Mileage } 6 \\
\text { Minutes }\end{array}$ & $449.55(300-730) \mathrm{m}$ \\
\hline 8 & Mets & $5.67(2.97-9.97)$ Mets \\
\hline 9 & $\begin{array}{l}\text { Total Carbohydrates } \\
\text { Consumption }\end{array}$ & $533.22(233.87-3534.75) \mathrm{gr}$ \\
\hline 10 & Total Protein Consumption & $101.77(26.84-723.94) \mathrm{gr}$ \\
\hline 11 & Total Fat Consumption & $57.14(12.84-430.14) \mathrm{gr}$ \\
\hline 12 & $\begin{array}{l}\text { Frequency of Carbohydrate } \\
\text { Consumption }\end{array}$ & 8.46 (3.57-20.89) kali \\
\hline 13 & $\begin{array}{l}\text { Frequency of Protein } \\
\text { Consumption }\end{array}$ & $6.55(1.2-45.71)$ times \\
\hline 14 & $\begin{array}{l}\text { Frequency of Fat } \\
\text { Consumption }\end{array}$ & $2.75(0.29-22.5)$ times \\
\hline
\end{tabular}


Table 1 was found that the characteristics of manufacturing workers have an age with a mean value of 35 years, a work period with a mean value of 11.5 years. For physical capacity (fitness) the value of strength was 5.67 Mets. The average circumference of workers was $84.96 \mathrm{~cm}$, but some reach $97 \mathrm{~cm}$. The height of manufacturing workers in Indonesia ranges from $155-170 \mathrm{~cm}$ and weighs varying from 33 to $127 \mathrm{~kg}$. Manufacturing workers sleep an average of 6.5 hours a day, but some only sleep about 4 hours per day. Carbohydrate, Protein, and Fat Intake with mean 533.22 gr, 101.77 gr and 57.14 gr. Manufacturing workers consumed more high-carbohydrate foods with an average of 8.5 times per day, even up to 20 times per day. However, for fat aspuan less frequently with an average of 3 times a day and some even less than once a day.

Table 2. Individuals Characteristics in the Category Variable in the Research Subjects

\begin{tabular}{|c|c|c|c|}
\hline No & Variable & Number & $(\%)$ \\
\hline \multirow[t]{3}{*}{1} & $\operatorname{Sex}$ & & \\
\hline & a. Male & 113 & 94.2 \\
\hline & b. Female & 7 & 5.8 \\
\hline \multirow[t]{3}{*}{2} & Age & & \\
\hline & Adult ( $\geq 40$ Years) & 36 & 30 \\
\hline & Adolescent (<40 Years) & 84 & 70 \\
\hline \multirow[t]{3}{*}{3} & Married Status & & \\
\hline & a. Married & 33 & 27.5 \\
\hline & b. Single & 87 & 72.5 \\
\hline \multirow[t]{4}{*}{4} & Habit of Drinking Tea (Cup) & & \\
\hline & a. Not & 47 & 39.2 \\
\hline & b. $1-2$ & 66 & 45 \\
\hline & c. $>2$ & 7 & 5.8 \\
\hline \multirow[t]{3}{*}{5} & Frequency of Physical Activity & & \\
\hline & a. Good ( $\geq 3$ times / week) & 114 & 95 \\
\hline & b. Poor (<3 times / week) & 6 & 5 \\
\hline \multirow[t]{3}{*}{6} & Sleep Duration & & \\
\hline & a. Good ( $\geq 6$ hours) & 101 & 84.2 \\
\hline & b. Poor (<6 hours $)$ & 19 & 15.8 \\
\hline \multirow[t]{5}{*}{7} & Years of service & & \\
\hline & $31-40$ & 3 & 2.5 \\
\hline & $21-30$ & 24 & 20 \\
\hline & $(11-20)$ & 33 & 27.5 \\
\hline & $(1-10)$ & 58 & 48.3 \\
\hline
\end{tabular}




\begin{tabular}{|c|c|c|c|}
\hline No & Variable & Number & $(\%)$ \\
\hline \multirow[t]{4}{*}{8} & Weight & & \\
\hline & a. Normal & 34 & 28.3 \\
\hline & b. Sufficient & 11 & 9.2 \\
\hline & c. Over (Overweight and Obesity) & 74 & 61.7 \\
\hline \multirow[t]{5}{*}{9} & Blood pressure & & \\
\hline & Normal & 32 & 26.7 \\
\hline & Pre Hypertension & 65 & 54.2 \\
\hline & Grade I Hypertension & 17 & 14.2 \\
\hline & Grade II Hypertension & 6 & 5 \\
\hline \multirow[t]{3}{*}{10} & Central Obesity & & \\
\hline & a. Normal & 82 & 68.3 \\
\hline & b. Central Obesity & 38 & 31.7 \\
\hline \multirow[t]{4}{*}{11} & Protein Category & & \\
\hline & a. Appropriate & 12 & 10 \\
\hline & b. Less & 16 & 13.3 \\
\hline & c. Over & 92 & 76.7 \\
\hline \multirow[t]{4}{*}{12} & Carbohydrate category & & \\
\hline & a. Appropriate & 14 & 11.7 \\
\hline & b. Less & 17 & 14.2 \\
\hline & c. Over & 88 & 73.3 \\
\hline \multirow[t]{4}{*}{13} & Fat Intake & & \\
\hline & a. Appropriate & 15 & 12.5 \\
\hline & b. Less & 64 & 53.3 \\
\hline & c. Over & 41 & 43.2 \\
\hline \multirow[t]{3}{*}{16} & Physical Capacity Category & & \\
\hline & a. Less & 29 & 24.2 \\
\hline & b. Enough & 91 & 75.8 \\
\hline
\end{tabular}

Based on Table 2, it was found that 94.2\% (117 people) were male workers with $72.5 \%$ unmarried. The age of manufacturing workers was $70 \% \quad(84$ people) under 40 years. The work period was about half as low as 10 years, but there are also those who work for more than 20 years. The physical condition $61.7 \%$ of workers were overweight, but the physical capacity based on the workload ( 4.5 meters) was sufficient, namely $75.8 \%$. Among workers, it was found that about $80 \%$ had normal blood pressure or pre-hypertension in manufacturing workers, it was found that $31.7 \%$ had a large abdominal circumference. Adequate intake of carbohydrates, protein, and fat were around $10 \%$. As much as $73.3 \%$ excess carbohydrate intake as well as $76.7 \%$ excess protein intake. In contrast to fat intake, there was $43.2 \%$ excess but there is $53.3 \%$ less. 
Table 3. Relationship of Physical Capacity (Fitness) in Numeric Variable with Other Risk Factors

\begin{tabular}{|c|c|c|c|}
\hline Variable Dependent & Variable Independent & $\mathbf{N}$ & $\mathbf{P} *$ \\
\hline \multirow{18}{*}{$\begin{array}{c}\text { Physical Capacity (METS) } \\
5.67(2.97-9.97)\end{array}$} & Years of service & & \multirow{3}{*}{0.259} \\
\hline & Working period $>15$ years & 47 & \\
\hline & Service Period $\leq 15$ & 71 & \\
\hline & Age & & \\
\hline & Old Age $(\geq 40$ Years $)$ & 36 & \multirow{2}{*}{0.005} \\
\hline & Young Age ( $<40$ Years) & 84 & \\
\hline & Sports Activity & & \\
\hline & Less exercise $(<3 \mathrm{x} /$ week $)$ & 40 & \multirow{2}{*}{0.207} \\
\hline & Enough Exercise ( $\geq 3 \mathrm{x} /$ week $)$ & 18 & \\
\hline & Carbohydrate intake & & \\
\hline & Not Appropriate & 105 & \multirow{2}{*}{0.934} \\
\hline & Appropriate & 14 & \\
\hline & Protein Intake & & \\
\hline & Not Appropriate & 108 & \multirow{2}{*}{0.02} \\
\hline & Appropriate & 12 & \\
\hline & Fat intake & & \\
\hline & Not Appropriate & 105 & \multirow{2}{*}{0.12} \\
\hline & Appropriate & 15 & \\
\hline
\end{tabular}

* Mann Whitney

Table 3 showed that the physical capacity of manufacturing workers has met value between 3-10 meters and a mean value of 5.67 meters. Physical Capacity was affected by age $(\mathrm{p}=0.0045)$ while the influential intake was protein $(\mathrm{p}=0.02)$. Other statistical tests showed that the physical capacity of workers was not related to length of work and physical activity.

Table 4. Relation of Physical Capacity (Fitness) in Category Variable with Other Risk Factors

\begin{tabular}{llcccc}
\hline No & Category & \multicolumn{2}{c}{$\begin{array}{c}\text { Physical Capacity } \\
\text { Inappropriate Appropriate }\end{array}$} & $\mathbf{p}^{*}$ & OR (95\% CI) \\
\hline $\mathbf{1}$ Age & 16 & 20 & 0.01 & $4.37(1.81-10.58)$ \\
$\quad$ Adult $(\geq 40$ Years $)$ & 13 & 71 & & \\
$\quad$ Adolescent (<40 Years) & 1 & 6 & 1 & $0.51(0.05-4.38)$ \\
$\mathbf{2}$ Sex & 28 & 85 & & \\
$\quad$ Female & & & & \\
$\quad$ Male & 15 & 14 & & \\
$\mathbf{3}$ Years of service & 32 & 57 & 0.13 & $1.91(0.82-4.45)$ \\
$\quad>15$ years & & & \\
$\quad \leq 15$ years & &
\end{tabular}




\begin{tabular}{|c|c|c|c|c|c|}
\hline \multirow{2}{*}{$\begin{array}{l}\text { No } \\
4\end{array}$} & \multirow{2}{*}{$\begin{array}{r}\text { Category } \\
\text { Duration of Sleep }\end{array}$} & \multicolumn{2}{|c|}{$\begin{array}{c}\text { Physical Capacity } \\
\text { Inappropriate Appropriate }\end{array}$} & \multirow[t]{2}{*}{$\mathbf{p}^{*}$} & \multirow[t]{2}{*}{ OR (95\% CI) } \\
\hline & & & & & \\
\hline & Good (<6 hours) & 5 & 10 & \multirow{2}{*}{0.52} & \multirow{2}{*}{$1.60(0.49-5.15)$} \\
\hline & Poor ( $\geq 6$ hours) & 24 & 77 & & \\
\hline \multicolumn{6}{|c|}{5 Sports } \\
\hline & Poor (<3x / week $)$ & 27 & 87 & \multirow{2}{*}{0.63} & \multirow{2}{*}{$0.62(0.11-3.58)$} \\
\hline & Good $(\geq 3 \mathrm{x} /$ week $)$ & 2 & 4 & & \\
\hline \multirow{3}{*}{7} & Married Status & & & & \\
\hline & Single & 6 & 27 & 0.34 & $0.61(0.23-1.68)$ \\
\hline & Married & 23 & 64 & & \\
\hline \multirow{3}{*}{8} & Category of Carbohydrat & & & & \\
\hline & Inappropriate & 27 & 78 & 0.51 & $2.08(0.44-9.88)$ \\
\hline & Appropriate & 2 & 12 & & \\
\hline \multirow{3}{*}{9} & Protein Intake Category & & & & \\
\hline & Inappropriate & 25 & 83 & 0.48 & $0.60(0.17-2.16)$ \\
\hline & Appropriate & 4 & 8 & & \\
\hline \multirow{3}{*}{10} & Fat Intake Category & & & & \\
\hline & Inappropriate & 27 & 78 & 0.52 & $2.25(0.48-10.61)$ \\
\hline & Appropriate & 2 & 13 & & \\
\hline
\end{tabular}

*Chi-Square

Statistical calculations to find the relationship between physical capacity and other factors found that age was significant to physical capacity with $\mathrm{p}=0.01$ with $\mathrm{OR}$ (95\% CI) 4.37 (1.81-10.58).

The effect of intake on physical capacity was found to be unrelated. In Carbohydrates, Protein, and Fat intake, it was found that there was no significant difference between workers and sufficient physical capacity or those with less physical capacity. Besides that, there was no relationship between individual factors such as marital status, sleep duration, and sports activities among workers.

\section{DISSCUSION}

Data distribution in six manufacturing companies throughout Indonesia was found not homogeneous. This can be due to the inconsistencies in policies in each company, regional

characteristics, and regional economy. The applicable government standards were still indicated by the existence of healthy information. Some large manufacturing companies have thought about hiring workers based on their workload. Another cause of the inhomogeneity of manufacturing workers in Indonesia is that the work system in companies is still familial and semi-formal.

Of the age distribution, all enter productive age, however, there were some workers above the productive age ( 56 years old). However, thirty percentages of manufacturing workers were over 40 years old. Yong Kang Cheah, 2014 said that younger people are more active than older people with an OR of 0.985 (0.985- 0.990) with the main factor being the degeneration process of body metabolism and degradation. The working period that spreads from 1 year to 39 years can affect workers in diet and fitness. Sagara et al., (2009) said that the longer middle age 
workers work, the lazier they are to exercise, a diet high in calories and low in carbohydrates.

In addition, manufacturing workers are dominated by male sex $(94.2 \%)$, this condition was in accordance with the workload in manufacturing (4.5 Mets). As many as $72.5 \%$ were unmarried, this condition led to an irregular eating pattern and uncontrolled intake. Win et al., (2015) said that physical activity were influenced by several factors such as age, gender, education level, and income level. Worker habits such as exercise and sleep duration were relatively good, namely $95 \%$ and $84.2 \%$. This good daily habit was able to support the physical capacity of workers by being shown the Physical Capacity category, the category was quite $75.8 \%$. Some workers only sleep for about 4 hours a day even though their workload was in the medium category and the working hours are usually long. This situation can affect the health conditions for manufacturing workers.

This study also found that manufacturing workers have tension in the normal category and prehypertension was $80.9 \%$. This is in accordance with Jakicic et $a l .,(2019)$ in their meta-analysis, stated that people who have moderate activity will increase their health status such as fitness, protection from high blood pressure, etc. In addition, many manufacturing workers have a smoking habit. This study was more than $50 \%$ smoked. This needs to be a concern because research conducted by Lestari, (2017) found that smoking is a risk factor for metabolic disorders in workers.

In manufacturing workers, it was found that $61.7 \%$ were overweight or obese, but did not have central obesity $(68.3 \%)$. In contrast to the research of Sangroula and Uprety, (2020) said manufacturing workers in India were $31 \%$ obese. This may occur because according to research by Zhou et al., (2017) conducted in China, it was suggested that a person's nutritional knowledge did not related to the incidence of obesity in adults. According to this study, one of the reasons is because in that country, the guidelines regarding the relationship between nutritional knowledge, nutritional status, and the factors that influence it were still limited and not systematically arranged thus a person with good nutritional knowledge cannot combine diet with physical activity, which was regularly proven. increasing their weight.

Diets vary widely where the intake of macronutrients varies widely, but according to government recommendations only about $10 \%$, namely, carbohydrates according to $11.7 \%$, frequency 8.46 times (533.22 gr), fat according to $12.5 \%$, frequency 2.75 times ( $57.14 \mathrm{gr}$ ), and protein according to $10 \%$, Frequency 6.55 times (101.77 gr). This is in accordance with Levesque, (2011) calorie intake was influenced by one person's workload. Win et al., (2015) also said that her calorie intake was due to work factors which would later lead to weight gain and decreased fitness for workers. Another factor that can cause an increase in food intake is excess body weight. Rogers and Brunstrom, (2016) said that people who are overweight are more likely to eat more.

Theoretically, physical capacity was influenced by several factors such as individual characteristics, exercise habits, intake factors, and illnesses. In this study, the relationship between physical capacity and numerical or categorical variables (sufficient and insufficient) was sought with other factors. Based on the results of the Spearmen test between physical capacity (numerical) and related factors, there is no correlation and meaning. Factors of age, years of work, length of sleep, total calorie intake, and work climate did not affect the value of physical capacity.

This condition is possible because the age of the workers is relatively young compared to the workload which is only moderate ( 4.5 meters). For the tenure, due to no new employees, it is possible to adapt the workers. Adaptation can occur after 1012 weeks of work. The length of sleep is sufficient to cause the physical capacity of 
the workers is not disturbed. Besides that, excessive intake of workers causes workers not to lack energy for their workload.

According to the Mann Whitney test, the significance of protein intake was $p$ $=0.02$ and age $p=0.005$. The intake of protein that is inappropriate (insufficient or excessive) can lead to reduced physical capacity. This situation is possible because protein is a substance that cannot be stored, if too much is removed by the body. This disposal also requires energy for metabolism and a considerable amount of water. However, protein is the body's last reserve in forming energy if needed. The age factor has an effect, with increasing age, naturally the organ function (respiration, heart, and muscles) decreases hence physical capacity also decreases. However, the Chi-Square test found that age had an effect on physical capacity with $\mathrm{p}=0.01$. This is in accordance with the body's physiology. The number of meaningless results is in accordance with the literature that a person's physical capacity is influenced by many factors and no factor is dominant.

The description of macronutrient intake in this study compared to (Ministry of Health Republic of Indonesia, 2019) shows that many workers have excess carbohydrates, protein and fat. The intake of carbohydrates and fats in this study was higher than protein. Research conducted by Kim and Song, (2019) stated that variations in both low and high macronutrient intake are associated with body fat levels and the risk of obesity. Moreover, variations in macronutrient intake are associated with metabolic abnormalities that can increase the risk of heart and blood vessel disease. Thus, the identification of macronutrients in obese people is quite important for an individual approach regarding an appropriate diet.

Eliane A.Castro, Eliana V. Carraca, Rocio Cupeiro, Bricia Lipez-Plaza, (2020) said that obesity is influenced by the number of calories in. It was not found that when balanced macronutrients can lead to obesity. This is consistent with this study which shows that the large amount of carbohydrate, fat, and protein consumption is the main cause of obesity in manufacturing workers.

This study found that protein intake can affect physical capacity. The intake of protein that was inappropriate (insufficient or excessive) can lead to reduced physical capacity. This situation was possible because protein is a substance that cannot be stored, if too much will be removed by the body. This disposal also requires energy for metabolism and a considerable amount of water. However, protein is the body's last reserve in forming energy if needed. The age factor has an effect, with increasing age, naturally the organ function (respiration, heart, and muscles) decreases thus physical capacity also decreases. The majority of protein consumed by manufacturing workers was vegetable originating from nuts such as tempeh and tofu. This protein in Indonesia is easy to obtain and the price is relatively cheap compared to animal protein.

In contrast to fat intake, there is $43.2 \%$ excess but there is $53.3 \%$ less. This situation is in accordance with the research conducted by Arheart and Lee, (2013). Research shows that food intake is influenced by a person's level of production. In most manufacturing workers, workers are not high income earners, this condition results in low fat intake for them. In addition, low fat intake is also possible because it is not easy to get fatty foods while working. Some workers prefer to bring perishable food items or food stalls provide low-fat but high-carbohydrate menu.

\section{CONCLUSION}

The majority of manufacturing workers are male and under 30 years of age. About a third of manufacturing workers are centrally obese. The characteristics of food intake that are in accordance with the nutritional adequacy recommended by the Indonesian population are only about $10 \%$. 
Half of the fat intake in manufacturing workers is less, this is different from the intake of carbohydrates and protein which tends to be excess. The physical capacity of the manufacturing workforce in Indonesia is categorized as sufficient as much as threequarter of the workload. Factors that influence physical capacity are age and adequate protein intake.

\section{REFERENCE}

Arheart, K. L. and Lee, D. J. (2013) 'among US workers', 54(1), pp. 101-105. doi:10.1097/JOM.0b013e31823ccaf a.Nutrient.

Basic Health Research (2018) 'Hasil Utama Riset Kesehatan Dasar (RISKESDAS)', Journal of Physics A: Mathematical and Theoretical, 44(8), pp. 1-200. doi: 10.1088/1751-8113/44/8/085201.

Eliane A.Castro, Eliana V. Carraca, Rocio Cupeiro, Bricia Lipez-Plaza, P. J. T. (2020) 'nutrients The E ff ects of the Type of Exercise and Physical Activity on Eating Behavior and Body Composition in', Nutrients, 12, p. $557 . \quad$ doi: doi:10.3390/nu12020557.

Fahmida Umi, D. H. D. (2011) Handbook Nutritional Assessment SEAMEORECFON. Jakarta: Univeritas Indonesia Press.

Grimani, A., Aboagye, E. and Kwak, L. (2019) 'The effectiveness of workplace nutrition and physical activity interventions in improving productivity, work performance and workability: A Systematic Review', pp. 1-12. doi: 10.21203/rs.2.12581/v2.

Issues, S. et al. (2002) 'American Thoracic Society ATS Statement: Guidelines for the Six-Minute Walk Test', 166, pp. 111-117. doi: 10.1164/rccm.166/1/111.

Jakicic, J. M. et al. (2019) 'Association between Bout Duration of Physical Activity and Health: Systematic
Review', Medicine and Science in Sports and Exercise, 51(6), pp. 1213-1219. doi: 10.1249/MSS.0000000000001933.

Kim, H. N. and Song, S. W. (2019) 'Associations between macronutrient intakes and obesity/metabolic risk phenotypes: Findings of the Korean national health and nutrition examination survey', Nutrients, 11(3). doi: 10.3390/nu11030628.

Lestari, D. I. (2017) 'Pengaruh Kebiasaan Merokok Terhadap Obesitas Dan Overweight Pada Karyawan Universitas Di Jakarta', Jurnal Muara Sains, Teknologi, Kedokteran dan Ilmu Kesehatan, 1(1), pp. 204-209. doi: 10.24912/jmstkik.v1i1.431.

Levesque, R. J. R. (2011) 'Obesity and Overweight', Encyclopedia of Adolescence, pp. 1913-1915. doi: 10.1007/978-1-4419-1695-2_447.

Ministry of Health RI. (2019) 'Angka Kecukupan Gizi2019', Menteri Kesehatan Republik Indonesia Peraturan Menteri Kesehatan Republik Indonesia, Nomor 65(879), pp. 2004-2006.

Rogers, P. J. and Brunstrom, J. M. (2016) 'Appetite and energy balancing', Physiology and Behavior, 164, pp. 465-471. doi: 10.1016/j.physbeh.2016.03.038.

Sagara, T. et al. (2009) 'Common risk factors for changes in body weight and psychological well-being in Japanese male middle-aged workers', Environmental Health and Preventive Medicine, 14(6), pp. 319-327. doi: 10.1007/s12199-0090100-2.

Sangroula, R. K. and Uprety, S. (2020) 'Factors associated with nutritional status of under five children among Satar Community of Bhadrapur Municipality, Jhapa, Nepal', International Journal Of Community Medicine And Public 
Health, 7(6), p. 2059. doi: $10.18203 / 2394-$ 6040.ijcmph20202452.

Shearer, J., Graham, T. E. and Skinner, T. L. (2016) 'Nutra-ergonomics: influence of nutrition on physical employment standards and the health of workers', Applied physiology, nutrition, and metabolism = Physiologie appliquee, nutrition et metabolisme, 41(6), pp. S165-S174. doi: 10.1139/apnm-2015-0531.

Win, A. M. et al. (2015) 'Patterns of physical activity and sedentary behavior in a representative sample of a multi-ethnic South-East Asian population: A cross-sectional study', BMC Public Health, 15(1), pp. 1-11. doi: 10.1186/s12889-0151668-7.

Yuan, J. et al. (2018) 'Evaluating the impacts of health, social network and capital on craft efficiency and productivity: A case study of construction workers in China', International Journal of Environmental Research and Public Health, 15(2), pp. 1-25. doi: 10.3390/ijerph15020345.

Zhou, L. et al. (2017) 'The impact of changes in dietary knowledge on adult overweight and obesity in China', PLoS ONE, 12(6), pp. 1-11. doi: 10.1371/journal.pone.0179551. 